\title{
Analisis Validitas Intrumen Penerapan Strategi PACER Terhadap Keterampilan Membaca Skimming Mahasiswa PGSD STKIP Adzkia
}

\author{
Ade Irma Suryani $^{1}$, Silfi Melindawati ${ }^{2}$, Maifit Hendriani ${ }^{3}$ \\ Prodi Pendidikan Guru Sekolah Dasar, STKIP Adzkia Padang ${ }^{123}$ \\ adeirmasuryani278@gmail.com ${ }^{1}$, silvimelinda01@gmail.com ${ }^{2}$, \\ maifithendriani@gmail.com ${ }^{3}$
}

\begin{abstract}
Abstrak
Penelitian ini bertujuan untuk mengetahui tingkat kelayakan intrumen penerapan strategi preview assess ahoose axpedite reeview (PACER) terhadapa keterampilan membaca skimming mahasiswa PGSD STKIP Adzkia. Metode penelitian yang digunakan yaitu deskriptif kuantitatif yaitu untuk mengetahui kelayakan instrumen pembelajaran yang dikembangkan. instrumen pembelajaran yang dikembangkan yaitu Rencana Pembelajaran Semester (RPS), Satuan Acar Perkuliahan (SAP), dan Rubrik Keterampilan Membaca Skimming. Hasil validasi Instrumen RPS yaitu 3,73 dengan kriteria sangat valid, sedangkan hasil validasi instrumen SAP memperoleh skor 3,76 dengan kriteria sangat valid, dan hasil validasi instrumen Rubrik Keterampilan Membaca Skimming memperoleh skor 3,80 dengan kriteria dangat valid. Hasil analisis menunjukkan bahwa instrumen RPS, SAP, dan Lembar keterampilan Membaca Skimming telah dirancang memperoleh nilai sangat valid dan layak digunakan.
\end{abstract}

Kata Kunci : Analisis, Validitas, Strategi PACER, Membaca Skimming 


\section{PENDAHULUAN}

Penelitian ini merupakan bagian dari penelitian eksperimen pengaruh strategi preview assess choose expedite review (PACER) terhadap keterampilan membaca skimming mahasiswa PGSD STKIP Adzkia. Strategi PACER adalah strategi membaca fleksibel yang bisa dimanfaatkan dalam membaca cepat, kecepatan baca yang ideal untuk memahami bacaan sehingga pembaca dapat membaca seefektif dan seefisien mungkin. Tujuan strategi PACER dalam membaca cepat adalah untuk materi bacaan sulit, namun hanya perlu memahami garis besarnya saja, atau untuk materi bacaan biasa-biasa saja dan ingin mendapatkan pemahaman umum, atau materi bacaan mudah dan ingin memahami secara mendetail (Prasrihamni, 2014). Membaca skimming adalah

Dalam penelitian ini juga bisa diketahui kelayakan instrumen yang akan digunakan untuk mengambil data dalam penelitian. Benar tidaknya data tergantung pada baik tidaknya intrumen pengumpulan data atau pengukur objek dari suatu variabel penelitian (Arifin, 2017) .

Pengumpulan data dibedakan menjadi dua yaitu tes dan nontes (Riyani et al., 2017). Adapun dalam penelitian ini berbentuk nontes yaitu dengan memberikan angket kepada pakar/ahli untuk mengukur kevalidan angket yang akan digunakan untuk mengambil data. Validitas nstrumen yang dinilai yaitu validas isi. Validitas isi dilakukan dengan kesepakan ahli (expert judgement).adapun langkah-langkah untuk membuktikan validitas isi yaitu: (1) memberikan kisi-kisi instrumen dan rubruk penskorannya, (2) masukan yang diharapkan dari ahli berupa kesesuaian komponen instrumen dengan indikator, indikator denga butir, dan kejelasan kalimat dalam butir, (3) berdasarkan masukan dari ahli tersebut, instrumen kemudian diperbaiki, (4) menilai ahli untuk menilai validitas butir berupa kesesuaian antara butir dengan indikator. (Retnawati, 2016)

Beberapa penelitian yang relevan : 1) hasil penelitian (Arifin, 2017) Validitas isi menggunakan kesepakatan ahli (expert) dimana instrumen dikatakan valid jika ahli meyakini bahwa instrumen tersebut mengukur pengusaan kemampuan yang didefinikan dalam domain. 2) hasil penelitian (Yusup, 2018) validitas instrumen mempermasalahkan sejauh mana pengukuran tepat dalam mengukur apa yang hendak diukur, validitas isi dinilai oleh ahli, dan dilakukan revisi sesuai 
saran.masukan para ahli.ahli bebas memberikan penilaian apakah instrumenvalid atau tidak. 3) Hasil penelitian (Suryani, 2018) hasil validasi instrumen RPP dengan nilai 3,69 dengan kategori sangat valid dari beberapa pakar/ahli. 4) hasil penelitan (Ihsan, 2015) Hasil akhir dari validitas isi adalah penilaian tentang kelayakan isi tes. rasio validitas isi sebagai hasil ukur penilaian ahli atas kesetujuannya terhadap validitas isi yang menggunakan teknik statistik kesepahaman antar penilai.

Berdasarkan kajian masalah dan penelitian sebelumnya maka pengukuran akan kelayakan suatu intrumen untuk mengambil data adalah suatu yang sangat diperlukan . Pada penelitian ini saya menganalisi validasi isi dari para ahli yang sesuai dengan kapakarannya. Instrumen saya berikan berupa kembar Rencana Pembelajaran Semester (RPS), Satuan Acara Perkuliahan (SAP), dan rubrik keterampilan membaca skimming. Adapun tujuan dari penelitian ini yaitu untuk mendeskripsikan validitas instrument yang digunakan pada penerapan strategi preview assess choose expedite review (PACER) terhadap keterampilan membaca skimming mahasiswa PGSD STKIP Adzkia.

Analisis instrumen RPS dilakukan untuk melihat apakah materi yang diajarkan telah sesuai dengan standar kompetensi (Helda \& Ramadhanti, 2019). Analisis juga dilakukan untuk melihat kekhasan dari RPS yang telah dikembangkan menggunakan strategi PACER. Selain tercantum bentuk pembelajaran yang ada di dalam RPS. RPS dalam perkuliahan ini yaitu mata kuliah Peningkatan Keterampilan Berbahas denan jumlah 3 sks. namun kerena semsester ini perkuliahan dilakukan secara dalam jaringan (daring), pertemuan matakuliah yang 3 sks ditambah menjadi 24 kali dan setiap pertemuan sksnya hanya memakan waktu 3 sks.

Satuan Acara perkuliahan memuat segala detail pembelajaran yang akan dilaksanakan dalam perkuliahan baik itu dari waktu, kegiatan pemebelajaran maupun penilaian. Apakah SAP yang sudah ada sudah sesuai dengan kebutuuhan mahasiswa dan tutuntuan KD maka perlu dilakukan analisis seperti memasukkan strategi yang tepat dalam mengajarkan. penjabaran proses pembelajaran ke dalam SAP juga perlu dilakukan. Salah satu materi yang diajarkan pada mata kuliah peningkatan keterampilan berbahasa adalan keterampilan membaca. namun tidak buat jenis keterampilan membaca yang harus dikuasai secara khusus. Maka dalam hal ini SAP yang sudah ada dilakukan analisisnya apakah sudah sesuai dengan kebutuhan 
Keterampilan membaca sekilas (skimming) yaitu adalah sejenis membaca yang membuat mata kita bergerak dengan cepat melihat, memperhatikan bahan tertulis untuk mencari serta mendapatkan informasi, penerangan (Sulistyo, 2015). Tujuan dari membaca skimming yaitu untuk melakukan pembacaan cepat secara umum dalam suatu bahan bacaan (Soedarso, 2010). Berdasarkan pengamatan peneliti dilapangan diketahui bahwa keterampilan membaca sekilas atau skimming mahasiswa STKIP Adzkia masih rendah. Adapun beberapa yang menjadi penyebab rendah keterampilan membaca skimming mahasiswa antara lain; 1) mahasisa tidak melakukan tahap membaca yang sahurusnya diperhatikan ketika kegiatan membaca akan dilakukan baik pra, saat dan pascabaca, 2) kegiatan prabaca sering diabaikan oleh mahasiswa saat kegiatan membaca karena seakan tidak penting untuk memperoleh pemahaman membaca, 3) mahasiswa mengabaikan teknik-teknik membaca yang seharunya dilakukan pada saat baca, 4) pemahaman akan bacaan menjadi rendah karna mahasiswa hanya terfokus pada kecepatan membaca.

\section{METODE PENELITIAN}

Penelitian ini merupakan penelitan deskriptif kuantitatif. dimana tujuan penelitian ini mendeskripsikan sesuatu sesuai dengan keadaan yang sebenarnya. (Sugiyono, 2016) metode deskriptif adalah metode yang digunakan untuk manganalisis data dengan cara mendeskripsikan atau menggambarkan data yang telah terkumpul sebagaimana adanya tanpa maksud membuat kesimpulan yang berlaku untuk umum atau generalisasi. Dalam penelitian ini, data dikumpulkan dengan memberikan instrumen berupa lembar RPS, SAP, dan Rubrik keterampilan membaca skimming. instrumen kemudian divalidasi oleh bebera pakar ahli.penelitian ini dilaksanakan pada bulan Agustus sampai dengan September 2020 bertemapat di STKIP Adzkia kota Padang. adapun objek penelitiannya yaitu instrument berupa lembar RPS, SAP dan penilaian keterampilan membaca skimming.

Jenis data dalam penelitan ini yaitu data kuantitatif. Adapun data dalam penelitian ini berupa data hasil validasi dari validator atau pakar yang digunakan untuk lihat pengaruh strategi preview assess choose expedite review (PACER) terhadap keterampilan membaca skimming mahasiswa PGSD STKIP Adzkia. Instrumen yang dugunakan adalah lembar validasi RPS, SAP, dan Rubrik keterampilan membaca skimming. 
Teknis analisis data dalam penelitian ini yaitu hasil skor dari lembar RPS, SAP, dan rubrik keterampilan membaca skimming yang sudah dinilai oleh para ahli. Adapun rumus menghitung data hasil penilaian lembar validasi oleh validator yaitu:

$$
\mathbf{R}=\frac{\sum_{\mathbf{j}=\mathbf{1}}^{\mathrm{n}} \mathbf{V i j}}{\mathbf{n m}}
$$

Dengan:

$$
\begin{array}{ll}
\mathrm{R} & \text { = rata-rata hasil penilaian dari para pakar } \\
\mathrm{Vij} & =\text { skor hasil penilaian para pakar ke-j criteria } \mathrm{i} \\
\mathrm{n} & =\text { banyaknya para pakar yang menilai } \\
\mathrm{m} & =\text { banyaknya criteria }
\end{array}
$$

Langkah penentuan tingkatan validitas menurut Widjajanti diperoleh melalui kategori seperti Tabel 1 berikut.

Tabel 1. Kriteria Penetapan Tingkat Kevalidan

\begin{tabular}{cc}
\hline Rentang & Kategori \\
\hline $1,00-1,99$ & Tidak valid \\
\hline $2,00-2,99$ & Kurang valid \\
\hline $3,00-3,49$ & Valid \\
\hline $3,50-4,00$ & Sangat valid \\
\hline Sumber : (Madona \& Nora, 2016)
\end{tabular}

\section{HASIL DAN PEMBAHASAN}

Hasil penelitian ini berupa skor yang diberikan oleh pakar/ahli terhadap instrumen yang telah dinilai. berukut rakapitulasi penilaian instrumen dari 3 orang validator.

\section{Rencana Pembelajaran Semester (RPS)}

Validasi RPS terdiri dari 18 item penilaian. Berdasarkan hasil validasi terdapat satu orang validator memberikan nilai 4 untuk semua item penilaian, sedangkan dua oerang validator yang lain memberikan 10 item dengan nilai 4, dan 10 item dengan nilai 3. Adapun 10 item yang memperoleh nilai 4 untuk 2 orang validator yaitu kejelasan dan kelengkapan identitas mata kuliah, ketepatan alokasi waktu, kesesuaian 
CPL dengan mata kuliah, kesesuaian CPMK dengan CPL, kesesuaian sub CPMK dengan CPMK, kejelasan dan kesesuaian deskripsi mata kuliah, kesesuaian indikator dengan sub CPMK, , kesederhanaan struktur kalimat, kesesuaian alokasi yang digunakan. Item yang me peroleh nilai 3 yaitu kesesuaian materi pembelajaran dengan CPMK, kesesuaian materi pelajaran dengan kemampuan dan kebutuhan belajar mahasiswa, kesesuaian metode/strategi dengan Sub CPMK, kesesuaian metode/strategi dengan materi pembelajaran, kesesuaian metode/strategi dengan karakteristik pembelajaran, kesesuaian penugasan dengan sub CPMK, pengggunaan bahasa sesuai dengan EB, pemilihan alokasi waktu berdasarkan pada tuntutan kompetensi dasar. Berdasarkan 18 aspek penilaian tersebut diperoleh rata-rata 3,73 dengan kriteria sangat valid.

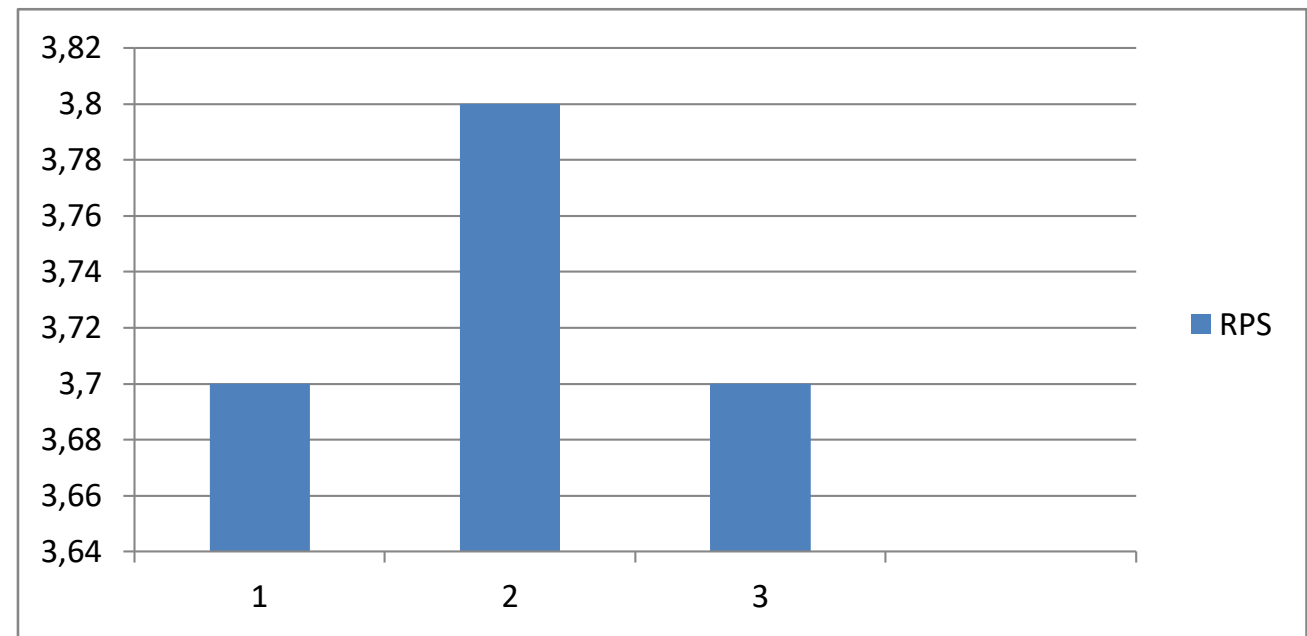

Grafik 1. Hasil Rekapitulasi Validasi Instrumen Penelitian RPS

\section{Satuan Acara Perkuliahan}

Validasi SAP terdiri dari 13 item penilaian. Berdasarkan hasil validasi item yang memperoleh skor 4 berjumlah 10 item dan 3 item berjumlah 3 . Adapun 10 item yang memperoleh nilai 4 yaitu kejelasan dan kelengkapan identitas mata kuliah, kesesuaian sub CPMK dengan materi perkuliahan dan metode pembelajaran, sistematika penyusunan SAP, kesesuaian uraian kegiatan pembelajaran keterampilan membaca skimming menggunakan PACER, kejelasan kegiatan pembelajaran, kelengkapan instrumen evaluasi, penggunaan bahasa sesuai dengan EBI, bahasa yang digunakan komunikatif, kesesuaian alokasi waktu yang digunakan, dan rincian waktu untuk setiap tahap pembelajaran . Berdasarkan 13 aspek penilaian tersebut diperoleh rata-rata 3,76 dengan kriteria sangat valid. 


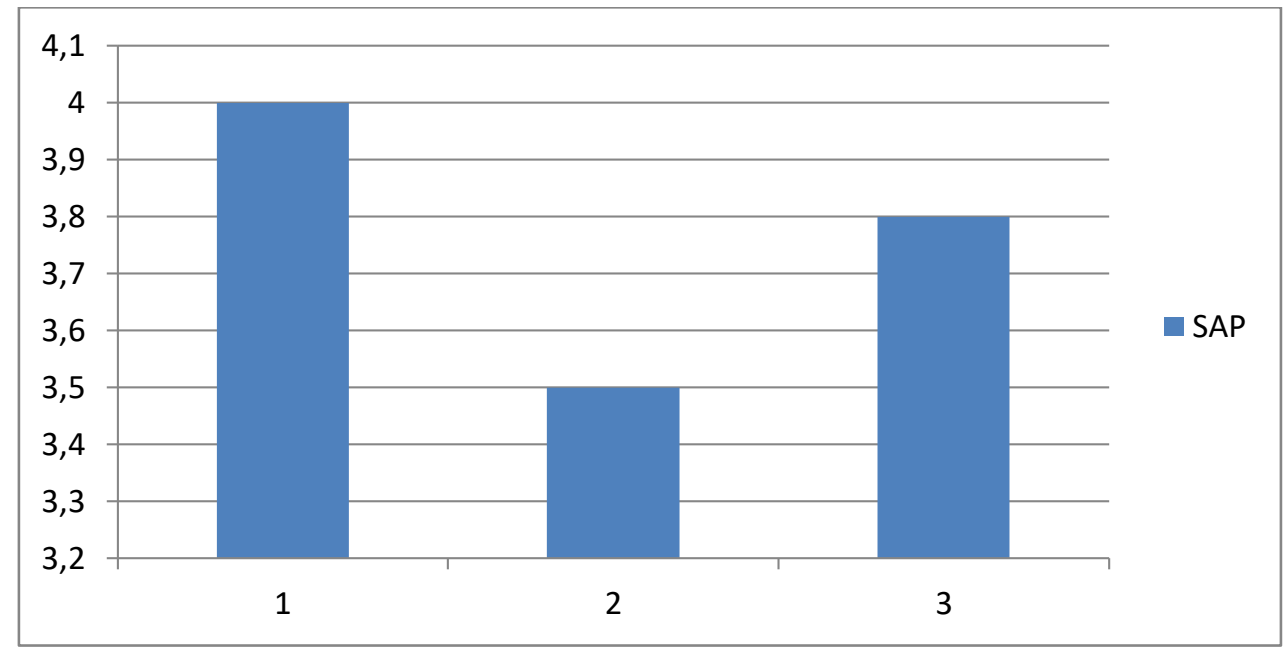

Grafik 2. Hasil Rekapitulasi Validasi Instrumen Penelitian SAP

\section{Rubrik keterampilan membaca skimming menggunakan PACER}

Validasi Rubrik keterampilan membaca skimming terdiri dari 5 item penilaian sesuai dengan langkah-langah strategi PECER.. Berdasarkan 5 aspek penilaian tersebut diperoleh rata-rata 3,8 dengan kriteria sangat valid.

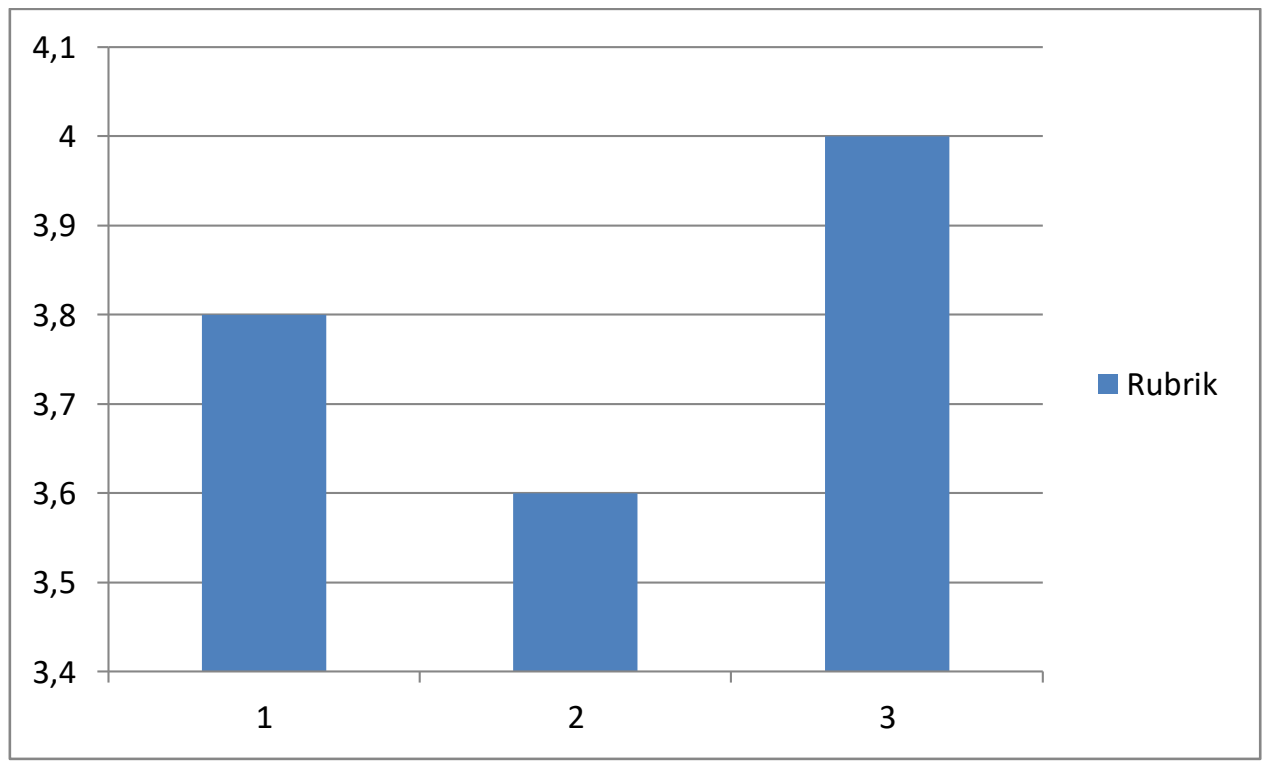

\section{KESIMPULAN}

Berdasarkan hasil validasi instrumen oleh validator ahli/pakar diperoleh hasil validitas untuk Rencana Pembelajaran Semester (RPS) diperoleh rata-rata 3,73 denga kriteria sangat valid. Validitas Satuan Acara Perkuliahan (SAP) memperoleh skor 
nilai 3,76 dengan kriteria sangat valid, dan validitas rubrik lembar keterampilan membaca skimming memperoleh skor 3,8 dengan kriteria sangat valid.

Dalam melakukan validitas instrumen khususnya validasi isi sebaiknya menggunakan lebih banyak pakar/ahli yang melakukan penilaian, agar diperoleh hasil instrumen yang lebih baik. Kami sebagai peneliti mengucapkan terimakasih kepada Kemenristek Dikti atas hibah dana penelitian tahun 2020, sehingga kami dapat melakukan Tri Dharma Perguruan Tinggi dengan lancar dan semoga peneliti dapat mengembangkan riset ini pada tahun.

\section{DAFTAR PUSTAKA}

Arifin, Z. (2017). Kriteria Instrumen Dalam Suatu Penelitian. Jurnal Theorems (the Original Research of Mathematics), 2(1), 28-36.

Helda, T., \& Ramadhanti, D. (2019). Analisis Dan Validasi Perangkat Pembelajaran Sintaksis Berbasis Problem Based Learning (Pbl) (Analysis and Validation of Syntax Learning Tool Based Onproblem Based Learning). Metalingua: Jurnal Penelitian Bahasa, 16(2), 285. https://doi.org/10.26499/metalingua.v16i2.212

Ihsan, H. (2015). Validitas Isi Alat Uukur Penelitian: Konsep Dan Panduan Penilaiannya. PEDAGOGIA Jurnal Ilmu Pendidikan, 13(3), 173. https://doi.org/10.17509/pedagogia.v13i3.6004

Madona, A. S., \& Nora, Y. (2016). PENGEMBANGAN MODUL IPS BERBASIS MULTIMEDIA INTERAKTIF UNTUK SISWA KELAS IV SEKOLAH DASAR. Jurnal Pelangi, 8(2), 221-228.

Prasrihamni, M. (2014). Peningkatan Keterampilan Membaca Sekilas dengan Menggunakan strategi PACER di Kelas IV SD N 19 ATB Kota Padang. Universitas Negeri Padang.

Retnawati, H. (2016). Heri Retnawati 9786021547984.

Riyani, R., Maizora, S., \& Hanifah, H. (2017). Uji Validitas Pengembangan Tes Untuk Mengukur Kemampuan Pemahaman Relasional Pada Materi Persamaan Kuadrat Siswa Kelas Viii Smp. Jurnal Penelitian Pembelajaran Matematika Sekolah (JP2MS), 1(1), 60-65. https://doi.org/10.33369/jp2ms.1.1.60-65

Saputra \& Handaka. (2017). Analisis Validitas Dan Reliabilitas Skala Perilaku Agresi. 2001, 260-268.

Soedarso. (2010). Speed Reading Sistem Membaca Cepat dan Efektiv. Gramedia Pustaka Utama.

Sugiyono. (2016). Metode Penelitian Kuantitatif, Kualitatif, R\&D. Alfabeta. 
Sulistyo. (2015). No Title空間像再生型立体映像の 研究動向. Nhk技研, 151, 10-17.

Suryani, A. I. (2018). Pengembangan bahan ajar membaca sekilas berbasis know want learned kelas V sekolah dasar. Autentik: Jurnal Pengembangan Pendidikan Dasar, 2(1), 9-19.

Yusup, F. (2018). Uji Validitas dan Reliabilitas Instrumen Penelitian Kuantitatif. Jurnal Tarbiyah: Jurnal Ilmiah Kependidikan, 7(1), 17-23. https://doi.org/10.18592/tarbiyah.v7i1.2100 